\title{
Contribution of universities to the socio-cultural progress of the Azerbaijan
}

$\mathrm{S}$ tate cultural and educational policy of Azerbaijan at the turn of the XX-XXI centuries is carried out under the conditions of a new social system, the polarization of social stratification, the transformation of ideas about values, and absence of a nation-wide consolidating idea. In this regard, the role of spiritual culture of both the individual and society as a whole is growing immeasurably. Indeed, spiritual (intellectual and moral) culture and its flagship are the most important social institute of education that can ensure social stability and consolidate the state and society to solve the most important national problems. The state interests of Azerbaijan are closely related to the development of an intercultural dialogue.

As long as the conference in Bologna defined the goals in education and in the cultural sphere, such guidelines were formulated by the intergovernmental conference on the use of cultural policy for development, at which the content of culture was determined as a complex of the most striking spiritual, material, intellectual, and emotional traits that characterize a society or a social group.

Culture includes not only science and education, art and literature but also a way of life, basic human rights, a system of values, life support, traditions, and worldview. In such a broad interpretation as a holistic social system, it represents all the positive features of a human life. Due to its systemic nature, culture, affecting the quality of life of individuals and communities, is the key to sustainable development and potentially leads to an increase in economic and social benefits.

Thus, the optimal cultural and educational policy should proceed from universal human norms and values, and domestic traditions. This approach takes into account the whole palette of ethnical and regional cultures, and combines them into single cultural space. There are three models for the development of the country's cultural and educational potential:

- firstly, the conservative model, which proceeds from the country's special path and its historical development;

- secondly, commercial, involving the integration of Azerbaijan into the world economic and cultural systems;

- thirdly, a model of dialogue of cultures, which is based on the partnership of Azerbaijan in world cultural development that allows us to maintain the socio-cultural dynamics in the country. 
Determining the features of the cultural process in Azerbaijan, it should be noted that the state cultural and educational policy of Azerbaijan stands out as a special system of sociocultural processes. The most important of its priority goals should include:

- firstly, the construction of a new axiology of being that creatively correlates national and historical traditions with the tasks of sociocultural modernization;

- secondly, the assistance to the population in the development of new forms of selfdetermination and self-expression;

- thirdly, the comprehensive development of the spiritual component;

- fourthly, the introduction of people to the whole diversity of cultures of mankind;

- fifthly, fostering a democratic and pluralistic worldview.

In determining the features of the cultural process at the present stage, it is necessary to pay special attention to the ethnic diversity of the cultural space of Azerbaijan. It creates the need for educational and cultural policies to proceed from some universal norms and principles in their universal humanity. It would be the basis that holds together local cultures in their constructive interaction in a single cultural and educational space.

Among such principles as guidelines for the cultural policy of the Republic of Azerbaijan can be attributed

- firstly, the principle of openness and democracy in structuring cultural policy while maintaining the continuity of cultural development, equal rights and opportunities for all citizens and social groups in creating and using material and spiritual values;

- secondly, the principle of the regulatory role of the cultural policy of the state in the formation of the socio-cultural situation;

- thirdly, the full consideration of the cultural identity of people, various local and territorial communities;

- fourthly, the principle of a single cultural space, etc. Moreover, the implementation of these principles is possible only if cultural policy is an integral part of the general public policy.

This state concern extends to the development of the strategic institute of spiritual culture, higher education, which is able to ensure "accelerated development and the rational use of intellectual potential in the interests of social development, and the steady growth of the general cultural and living standards of the people". ${ }^{74}$

Economic, political and social situation in Azerbaijan gives mandatory direction of cultural policy in the creation of a single sociocultural space in which different entities live, who agree to abide by common norms, despite the difference in interests. These norms ensure stable ties of the cultural environment in the republic, thereby contributing to the revival of the national culture of the people and ethnic groups as a necessary condition for overcoming tensions in interethnic relations and contradictions.

\footnotetext{
${ }^{74}$ F.T. Mamedov, Культурология [Culturology], Baku 2002, p.69.
} 


\section{Universities as a flagship of the spiritual culture of Azerbaijan}

The state is the foundation of stability and independence of national cultures guarantees them the right to self-expression and self-realization. At present, the desire of people to preserve their cultural identity and to protect spiritual values from standardization is becoming more and more conscious. A higher educational institution is the flagship of the formation of a spiritual culture of youth, which should be understood as a concrete historical phenomenon since it has different meanings in different historical periods (not to mention the critical and transitional periods); sociocultural phenomenon; a complex and multidimensional phenomenon in the social structure; as a product of the social structure of society, youth is differentiated in accordance with social strata; in youth, there is a final social stratification of people of the same age.

Youth is part of a chain of generations, where a generation is an objectively developing socio-demographic and cultural-historical community of people united by age boundaries and general conditions of formation and functioning in a concrete historical period of time. The generation is distinguished by a specific complex of anthropogenesis, sociopsychological, ideological, moral, and cultural values.

The bipolarity of the phenomenon is grounded on the fact that a generation is a community characterized by a tendency leading to discontinuity in the historical and cultural process as well as its continuity. Moreover, the nature of the community is considered be spatially chronological (positivist-naturalistic approach), ideological and spiritual (romantichumanitarian approach), historical-political (Marxism), and socio-demographic.

In the history of the formation of the theoretical and methodological apparatus of the sociology of generations, an article by the German sociologist C. Mannheim "The Problem of Generations" (1928) ${ }^{75}$ undoubtedly deserves attention. According to Mannheim, a generation is characterised by a certain "position" (Generationslagerung), a specific "relationship" (Generationszusammenhang) and a well-known "unity" (Generationsein-heit) ${ }^{76}$.

Each generation has its own temporal dimension and historical and cultural space. From the point of view of $\mathrm{K}$. Mannheim ${ }^{77}$, the change of generations is a universal process based on the biological rhythm of a human life. As a result, new participants appear in the historical and cultural process, and old ones disappear. This approach, in terms of the tendency, allows us to highlight generational and historical-cultural space.

Universities play a special place in society, being an institution of socialization of the young generation, striving to find new ideals, as well as an institution that preserves the continuity of national spiritual culture. In general, it should be noted that pedagogical activity is a condition for the continuity of generations. It grows from the culture of its era, is consistent with this culture and is aimed at its preservation and reproduction. However, at the same time, it is a prerequisite and condition for the further development of culture, and the emergence of fundamentally new phenomena in it. Genuine teachers of any era are concerned not only with the transfer, translation of existing experience, and accumulated knowledge, but

\footnotetext{
${ }^{75}$ K.Mannheim, The Problem of Generations, [in:] Essays on the Sociology of Knowledge, P.Kecskemeti (ed.), K.Mannheim, London 1952, p. 292.

${ }^{76}$ Ibidem, p. 294.

${ }^{77}$ Ibidem, p. 301-303.
} 
also with the development of the creative potential of the personality of their students, their abilities and skills to overcome the boundaries of the known, traditional. Thanks to this, it becomes possible to go beyond the stereotypes, to create conditions for the successful development of those who are capable not only of the reproduction of knowledge but also of creativity.

The specificity of spirituality as a phenomenon of both objective and subjective reality gives rise to contradiction and extremes in understanding its true essence. The spiritual life of a person is closely connected with the practical material side, and the role and place of the spiritual in his real life is determined by his innate qualities, the conditions of his education, training and upbringing, as well as his own personal activity.

Thus, spiritual culture is of great theoretical and practical importance as it allows the further development and development of the theory of spirituality within the framework of a single conceptual model and helps to meet the urgent needs of practice. In education, training and upbringing of the younger generation in the face of increasingly complex human relations with the surrounding world. The socialization of personality in universities is a research field for studying its formation with the domination of the spiritual and moral foundations of the process of lifelong education, training and upbringing, which allows us to derive these foundations as a foundation or basis for continuity, consistency, systematicity and goalsetting.

The spiritual and moral dimension of the activity of universities in Azerbaijan is due to the phenomenon of spirituality, which is considered in science as a reflection of the material Being of a person, as a qualitative characteristic of consciousness acquired in society in the process of familiarizing oneself with culture, as an essential characteristic of a person, which acts as a condition and the result of its development and self-development, external and internal transformations. Thus, spirituality is associated with familiarization, with intellectual and ethical values, the creative transformation of man and society, and the development of man as a free subject. The moral activity of an individual always implies the free choice of one or another value. From a pedagogical point of view, morality is understood as a way of mastering social experience, spiritual and practical activity. Morality includes internal spiritual qualities that govern a person, ethical standards, rules of behavior, and behavioral attitudes determined by these qualities.

Formation of a cultural man as a holistic personality with high intellectual, spiritual and moral qualities, objective knowledge, professional and practical skills, socially significant individual culture, conscious behavior, controlled emotions, and civic feelings, is valuable for society in the process of the university. It should be noted that pedagogical values are norms that regulate pedagogical activity and act as an intellectual-moral cognitive-acting system that serves as a mediating and connecting link between the prevailing public world outlook in the field of education and the activities of a teacher.

Pedagogical values depend on social, political, economic, and mental relations in society, which in many respects influence the development of pedagogy and educational practice. Pedagogical values vary in their level of existence. Thus, groups of pedagogical values, giving rise to each other, form an axiological model that has a holistic character. It manifests itself in the fact that values-goals determine values-means, and values-relations depend on values-goals and values-qualities, etc., i.e. they function as a whole. 
The introduction of a value context in the content of education, training and upbringing is an extremely important and widely discussed topic today. Although it is more correct to speak not about introducing values into the content of education (they are always present in it) but about their awareness, actualization, conscious design, and purposeful implementation in the process of pedagogical activity, on the consideration of values as the foundation of pedagogical activity, goals, and conditions for its development. In this context, pedagogical issues related to the relationship between traditional and innovative in teaching, the implementation of several innovative pedagogical concepts and technologies, and the modeling of complex pedagogical phenomena and processes are being updated.

In the process of the university, the necessary conditions are created for the formation of values, which emphasizes the importance of the teacher's participation in the process of forming values, i.e. the personal influence of the teacher and other significant adults, value dialogue, immersion in the value environment, designing value situations for living and awareness, and creating situations of value choice.

The unity of education, training and upbringing is the strategic goal of pedagogical activity. It is carried out in the co-creation of two partners who have common activity goals, within the framework of which they interact, the goal and result of which is a high spiritual culture of the individual - her knowledge, skills, organization, morality and creative activity. In general, education, training and upbringing, which is implemented in the university system, are the intellectual and moral base of pedagogical activity, focused on maintaining and developing the intellectual potential and moral values of society.

The concept of "key qualification" is widely used today in assessing the quality of training. The justification was made by D. Mertens based on the analysis of the socioeconomic and technical and economic characteristics of production and the nature of vocational education in modern society ${ }^{78}$. The main idea of the Mertens theory is to form a new generation of workers who can quickly adapt to dynamic production, move from one type of labor to another, and possess the knowledge and abilities necessary for a wide range of professions.

Of great methodological and substantive significance for solving these problems is the teaching at universities of general and special courses of cultural studies such as a science of human life, which passes on to the richest experience of the socio-cultural development of mankind to the younger generation. Universal culturological knowledge, culturological thinking, and systemic culturological analysis are indispensable for the correct understanding and solution of complex problems of modern development, regardless of human profession ${ }^{79}$.

The university of Azerbaijan, as a structural part of the spiritual culture of Azerbaijan, is included in the personality - society - society system. It is important to note that the structure, as an internal form of the system, which is a way of interconnection, the interaction among its constituent components acts as the basic concept of the system. The concept of structure should be understood as a necessary connection between the components of pedagogical activity. The specificity of the structure depends primarily on the nature of the

\footnotetext{
${ }^{78}$ D. Mertens, Schlueselqualifikation.Thesen zur Schulung fbr eine Moderne Geseltschaft [Key qualification. Theses on training for a modern company], Verlag W. Kohlhammer, Stuttgart, Berlin, Ruin, Mainz, 1974, p.96.

${ }^{79}$ F. T. Mamedov, Культура управления [Management Culture], Baku 2009, p.108-111.
} 
components of the system. Components in the philosophical sense are those structural units whose interaction provides the qualitative features inherent in the system.

Thus, the university as a cultural and educational center becomes the flagship of the spiritual culture of the nation. The influence of the universities of the Republic of Azerbaijan on the formation of the worldview of students is significant. We must consider the phenomenon of worldview as the most important component and the result of the development of the spiritual culture of society and the individual. It determines the harmonious development of the surrounding reality by people in the processes of cognitive activity and social interactions, in the conditions of professional education and labor, in individual human practice, and includes such components of the worldview as attitudes and beliefs, goals and objectives, principles of behavior and the meaning of the subject's relations in society. They serve as the basis for a creatively active, spiritual and moral life position of the personality, revealed in its cognitive, communicative and active practice.

The culture of society and worldview culture as an indicator of the socialization of personality in the spiritual and moral process of education are interrelated phenomena. The culture of society acts as the basic sociocultural, intellectual-value and cultural-educational environment, which, firstly, directly forms the individual's worldview. Secondly, culture ensures the integrity of the functioning of a personal worldview as a way of spiritual and practical mastery of the world by a person. Thirdly, it creates real conditions for the world outlook of personality development in the educational system in society.

University, in the spiritual culture of a nation, is an intellectual and moral resource maintained in the instinct of self-preservation of the human qualities in a human. This resource has the following composition:

1) humanitarian environment - the practice of accumulating and developing certain knowledge, skills and attitudes (mastering learning technologies, ways of working, forms and methods of communication, norms of behavior, value systems), fixed in meanings, symbols, and lifestyles of educational society;

2) reflective comprehension - thereby, the person acts as a spiritual and moral reflection of the practical orientation of the system of pedagogical activity;

3) socialization - the potential for reflective reflection on their actions.

The formation of the value world of the personality in the educational process has a holistic character and is carried out throughout life. It does not occur apart from learning. During learning and via learning, a person forms a significant part of his/her worldview, affirms himself/herself in some values and dissuades in others, the process of comprehension is based on the level of logical thinking of the personality, on the degree of its consistency, systemicity. The formation of the value world of the individual, of his/her moral world presupposes the closest connection with his/her mental and practical development. It is emphasized that the high level of development of the humanitarian culture of the individual also means the strengthening of integrative ties that contribute to the development of the internal harmony of the individual, and the general conjugation between value and intellectual components. 
The increased presence of Western foundations and organizations in the region has led, among other things, to a greater orientation towards Western forms of education due to the need to train specialists able to work with Western colleagues, as well as to achieve coherence between and the possibility of mutual conversion of diplomas and degrees ${ }^{80}$. The emergence of new training programs for specialists in the field of energy also stimulated the adoption of a Western form of organization of education.

It is necessary to develop democratic mechanisms for organizing the activities of universities. In Azerbaijan, the State Student Admission Commission became such an anticorruption mechanism, which has become a real effective means of combating abuse in the most difficult element of the educational system in this regard - admission to the university.

Systematic versatile cooperation between universities is becoming a means of positioning the state at the international level. Education in the era of globalization has become a kind of a hub in which the advantages and disadvantages and contradictions generated by the modern era are linked and reflected. The reform of the higher education system in Azerbaijan, the inclusion of the Azerbaijani higher school in the international educational space are indicative of the desire of Azerbaijan to take a worthy position in the world arena.

In this regard, an analysis of the problems associated with joining the Bologna Declaration, with the impact of globalization on the functioning of universities, focuses on international and network aspects of educational processes. The transformations taking place in the Republic of Azerbaijan also determine the modernization of the existing education system. For several years, a change in the content and structure of education has been going on in higher education, and its conceptual foundations are radically changing.

\section{The nature of the Bologna system and its implementation in Azerbaijan}

A new fundamental discipline has appeared for our country - cultural studies, which allows us to study and creatively use the historical experience of the development of world culture and civilization.

The leading idea of renewal of education is the Bologna concept of multilevel education. Multilevel is the organization of a multi-stage educational process, which provides the opportunity to achieve at each stage of education the level of education that meets the capabilities and interests of a person. The level is separated from the other by a different set of goals, training periods, and its own characteristics.

The multilevel system of higher education involves three levels: the first level general higher education ( 2 years), the second level - basic higher education - undergraduate ( 2 years of higher education +2 years of postgraduate), the third level - full higher education - master's program (4 years of undergraduate +2 years of postgraduate). Additionally, sometimes one more level is distinguished - doctoral studies. Importance in a multilevel system is continuity as a group of connections that combines different levels and provides an affordable transition from one level to another, regardless of professional specialization. The author's model of student training in the education system of Azerbaijan considers the principles of:

\footnotetext{
${ }^{80}$ J.S.Catterall, R. Jr.McGhee, The emergence of private postsecondary education in the former Soviet Republic of Azerbaijan, International Higher Education 1996, № 5, p. 3-5.
} 
1) the relationship of the educational and sociocultural process;

2) continuity and multi-level;

3) development of the potential of the student's personality culture without prejudice to his/her demand for the labor market.

Along with the term "key qualifications", Schelten uses the concept of "basic skills" 81. The project expert Oskarson ${ }^{82}$ gives the following definition: "Basic skills are personal and interpersonal qualities, abilities, skills and knowledge that are expressed in various forms in diverse situations of work and social life". For an individual in a developed market economy, there is a direct correlation between the level of available basic skills and the possibility of employment.

However, he emphasizes that basic skills as such are not tied to a particular profession or group of professions. They are more or less demanded by all professions. Moreover, they are not limited to purely professional functions but are qualities that are useful to any citizen of the modern society. In the UK, these basic skills are called "core skills" ${ }^{83}$ that enable the specialist to move from one specialty to another. Simon Shaw, noting the lack of a single definition, leads eight groups of basic skills ${ }^{84}$ :

1) basic skills such as literacy and numeracy;

2) life skills, namely relations with other people, skills of self-government, professional and social growth;

3) key skills: communication, problem and solving, teamwork;

4) social and civic skills, which include social activity, moral rules and values, and cooperation;

5) skills for gaining employment, for example information processing, adaptability to the situation, and independent decision-making;

6) entrepreneurial skills: independent activity, search and research of business opportunities;

7) management skills encompassing communication, counseling, analytical thinking, training, and instruction;

8) broad skills such as the ability to analyze, plan, and control;

Key skills are considered to improve the learner's prospects in gaining broad competence:

- competencies in performing several different work operations, most of which can be routine and predictable;

\footnotetext{
${ }^{81}$ A. Schelten, Einfbhrung in die Berufspadagogik [Introduction to professional education], Stuttgart 1991, p. 45-51.

${ }^{82}$ B. Oskarson, Базовые навыки как интегрируюший фактор учебного плана [Basic skills as an integrating factor in the curriculum], [в:] Оиенка качества профессионального овразования [[in:] Assessment of the quality of vocational education], V.I.Bidenko, J.vanZantworth (ed.), Moscow 2001, p.44-46.

${ }^{83}$ Ibidem, p. 45.

${ }^{84}$ S.Shaw, Development of Core Skills training in the Partner Countries, Final Report for the ETF Advisory Forum Sub-Group D, European Training Foundation, June 1998, p. 37-38.
} 
- competencies in a significant number of different operations performed in a variety of contexts. Some of the operations are complex, non-routine and provide for some individual responsibility and cooperation with other people;

- competencies in a wide variety of different work operations performed in a larger number of diverse contexts, many of which are complex and non-routine. A significant degree of responsibility and autonomy is assumed, and it is often required to lead other people and control their activities;

- competencies in the volume of complex technical or professional work operations carried out in a significant number of diverse contexts with a pronounced personal responsibility and independence;

- competence in the field of independent cognitive activity, based on the assimilation of ways to acquire knowledge from various sources of information;

- competence in the field of civil society activities (performing the roles of a citizen, voter, and consumer);

- competence in the field of social and labor activities (including the ability to analyze the situation on the labor market, evaluate own professional opportunities, navigate the norms and ethics of labor relations, and self-organization skills);

- competence in the domestic sphere (including aspects of their own health and family life);

- competence in the field of cultural and leisure activities (including the choice of ways and means of using free time that culturally and spiritually enrich a person).

Today, the formation of the scientific field of Azerbaijan, creation of human potential, and redistribution of specialists of different levels in the regions are evident. Considering their greatest demand in the new cultural and historical situation, universities play a significant role in this process.

\section{Streszczenie:}

W artykule omówiono szczególną rolę wyższych uczelni w Azerbejdżanie i ich miejsce w społeczeństwie jako instytucji socjalizacji młodego pokolenia dążącego do nowych ideałów, a także instytucji utrzymującej ciągłość rdzennej tożsamości kulturowej. Głównym argumentem tego artykułu jest młodzież uważana za niezbywalną część kolejnych epok, postrzegająca epokę jako społeczno-demograficzną i kulturowo-historyczną odrębność jednostek, powiązaną ze względu na przedziały wiekowe oraz wspólne życie i warunki pracy w konkretnym środowisku. Artykuł traktuje problem młodzieży jako siły intelektualnej i etycznej związanej ze zmianami w różnych sektorach życia społecznego w ramach obecnych przemian społecznych $\mathrm{w}$ Azerbejdżanie. Wreszcie, autor analizuje warunki finansowe, polityczne i społeczne w Azerbejdżanie i przedstawia obowiązkową analizę organizacji społecznej z myślą o stworzeniu jednolitego środowiska społeczno-kulturowego dla różnych grup etnicznych. 


\section{Słowa kluczowe:}

zjawisko wielowymiarowe, sztandarowe, moralność, młodzież, uniwersytet, społeczeństwo obywatelskie, globalizacja

\section{Key words:}

multidimensional phenomenon, flagship, morality, youth, university, civil society, globalization

\section{Bibliografia:}

1. A. Schelten, Einfbhrung in die Berufspadagogik [Introduction to professional education], Stuttgart 1991.

2. B. Oskarson, Базовые навыки как интегрирующий фактор учебного плана [Bаsіс skills as an integrating factor in the curriculum], [в:] Оиенка качества профессионального оьразования [[in:] Assessment of the quality of vocational education], V.I.Bidenko, J.vanZantworth (ed.), Moscow 2001.

3. D. Mertens, Schlueselqualifikation.Thesen zur Schulung fbr eine Moderne Geseltschaft [Key qualification. Theses on training for a modern company], Verlag W. Kohlhammer, Stuttgart, Berlin, Ruin, Mainz, 1974.

4. F.T. Mamedov, Культурология [Culturology]. Baku, 2002.

5. F. T. Mamedov, Культура управления [Management Culture], Baku 2009.

6. J.S.Catterall, R. Jr.McGhee, The emergence of private postsecondary education in the former Soviet Republic of Azerbaijan, International Higher Education 1996, № 5.

7. K.Mannheim, The Problem of Generations, [in:] Essays on the Sociology of Knowledge, P.Kecskemeti (ed.), K.Mannheim, London 1952.

8. S.Shaw, Development of Core Skills training in the Partner Countries, Final Report for the ETF Advisory Forum Sub-Group D, European Training Foundation, June 1998. 